\title{
Tinjauan Historis Kurikulum \\ Pesantren Sirajul Huda Kabupaten Karo
}

\author{
Muhammad Irsan Barus \\ Syadidul Kahar \\ Sekolah Tinggi Agama Islam Negeri, Mandailing Natal, Indonesia \\ mirsanbarus@gmail.com
}

\begin{abstract}
Islamic education is an education based on the value of Islamic teachings contained in the Qur'an and the hadith as well as the thinking of scholars in the history practice of Muslims. The process of Islamic education continues to grow thanks to traders and preachers all over Indonesia including North Sumatra. The history of Islamic education in the Karo Land begins with the Islam of the family of Sulaiman Tarigan. Sulaiman Tarigan's awareness of Islamic education motivated him to prepare a successor cadre for the Islamic development struggle. The work of preparing the cadres was established by establishing the Three Beringin School in 1925. The study expanded rapidly until the school moved to Kuala Baru and started the establishment of Sirajul Huda boarding school in 1994. In addition they learn to read and write the Koran and Malay.
\end{abstract}

Keywords: History, Islamic Education, Karo Land

\section{Pendahuluan}

Pendidikan Islam diartikan sebagai pendidikan yang didasarkan pada nilai-nilai ajaran Islam yang tercantum dalam Alquran dan hadis serta pemikiran para ulama dalam praktik sejarah umat Islam. ${ }^{1}$ Pendidikan Islam

\footnotetext{
Abuddin, Nata, Manajemen Pendidikan, cet. Ke-3, (Jakarta: Kencana Prenada Media Group, 2008), hlm. 173.
} 
adalah pendidikan yang bertujuan membentuk individu menjadi makhluk yang bercorak diri dan berderajat tinggi menurut ukuran Allah. ${ }^{2}$

Pendidikan Islam merupakan proses pewarisan dan pengembangan budaya manusia yang bersumber dan berpedoman pada ajaran Islam. Oleh karena itu, ada yang berpendapat bahwa sejarah pendidikan Islam dimulai sejak Nabi Adam dengan alasan bahwa substansi yang disampaikan dalam pendidikan Islam adalah nilai-nilai ketauhidan, dan itu telah dilakukan semenjak Nabi Adam. Sementara yang lain mengatakan bahwa pendidikan Islam dimulai sejak diutusnya Nabi Muhammad SAW dengan alasan bahwa ajaran Islam yang dibawa oleh Nabi Muhammad SAW telah menemukan kesempurnaan wahyu Allah SWT. ${ }^{3}$

Ada beberapa teori kedatangan Islam ke Indonesia. Pertama, teori India. Sarjana Belanda kebanyakan menyebutkan bahwa kedatangan Islam ke Indonesia berasal dari India. Di antara sarjana tersebut adalah Pijnappel, Moquette dan Snouck Hugronje. Periode yang paling mungkin permulaan penyebaran Islam di Indonesia menurut Hugronje adalah pada abad ke-12. Kedua, teori Arab yang berpendapat bahwa Islam ke Indonesia berasal dari Arab. Teori ini didukung oleh sejumlah sarjana di antaranya adalah Crawfurd, Niemann, dan Naquib al-Attas. ${ }^{4}$

Pada tanggal 17-20 Maret 1963 diadakan seminar di Medan tentang masuknya Islam ke Indonesia. Hasil seminar berkesimpulan bahwa Islam masuk ke Indonesia pada abad pertama Hijriah dan langsung disebarkan dari Arab. Daerah yang mula-mula dimasuki oleh Islam adalah daerah pesisir Sumatera dan kerajaan Islam pertama adalah kerajaan Aceh. Penyiaran Islam dilakukan secara damai oleh pedagang dan kedatangan Islam ke Indonesia membawa perubahan yang sangat besar terhadap peradaban ketika itu. ${ }^{5}$

Ahli sejarah umumnya sependapat bahwa Islam pertama masuk ke pulau Sumatera bagian Utara di daerah Aceh. Dilihat dari sejarah perjalanan Marco Polo, dalam perjalanannya pulang dari Tiongkok, ia singgah di Aceh pada tahun 1292 M. Menurut keterangannnya, di Perlak telah ada rakyat yang beragama Islam. Begitu juga dengan perjalanan Ibnu Bathuthah, pengembara Magribi yang masyhur $(725 \mathrm{H}=1325 \mathrm{M})$. Dalam perjalanannya

\footnotetext{
${ }^{2}$ Burlian Somad, Beberapa Persoalan dalam Pendidikan Islam, (Jakarta: Al-Ma'arif, 1981), hlm. 21.

${ }^{3}$ QS. Al-Maidah, 5:3.

4 Haidar Putra Daulay, Sejarah Pertumbuhan dan Pembaruan Pendidikan Islam di Indonesia, (Jakarta: Kencana Prenada Media Group, 2014), hlm. 11.

${ }^{5}$ Ibid, hlm. 12.
} 
pulang pergi ke Tiongkok, ia singgah di Pase. Pada masa itu Pase telah menjadi kerajaan Islam di bawah perintah Raja yang bernama Al-MalikuZ Zahir. Inilah yang menjadi alasan kuat bahwa Islam masuk ke Indonesia tepatnya di daerah Aceh. ${ }^{6}$

Masuknya Islam ke Indonesia tidak terhenti pada satu daerah saja. Islam terus berkembang termasuk dalam hal ini ke Tanah Karo Sumatera Utara berkat para pedagang dan pendakwah. Masyarakat Karo sangat menjunjung tinggi adat-istiadat. Adat-istiadat sangat diutamakan, bahkan dalam tingkat tertentu, bagi orang Karo sendiri, kedudukan adat jauh lebih tinggi dari agama. Artinya, dalam kasus-kasus tertentu, bisa saja hukum agama ditinggalkan demi melaksanakan hukum adat. Sebagai contoh, sebuah keluarga Karo dapat saja meninggalkan aturan-aturan Islam tentang hukum waris dan beralih untuk menggunakan hukum adat. ${ }^{7}$

Adat masih mendominasi kehidupan masyarakat Karo daripada agama. Tidak ada tawar menawar adat bagi orang Karo. Terkadang tidak dapat dipisahkan suatu acara yang dilaksanakan masyarakat Karo, apakah itu acara agama, acara adat atau acara yang merupakan kebiasaan saja. ${ }^{8}$

Pemeluk agama Islam di Tanah Karo masih minoritas. Walaupun pada tahun 1953 dan 1978 diadakan upacara persyahadatan besar-besaran di beberapa tempat di Tanah Karo tidak lantas membuat pemeluk agama Islam menjadi mayoritas. Tahun 1953 Sulaiman Tarigan sebagai Kepala Jabatan Agama di Kabanjahe yang dibantu oleh Abdul Salam Tarigan melaksanakan pensyahadatan ratusan masyarakat Karo. Pensyahadatan ratusan masyarakat Karo ini berlangsung di desa Kutambaru dan Singgamanik. Peristiwa ini merupakan peristiwa yang fenomenal karena banyaknya masyarakat Karo yang memeluk agama Islam. Begitu juga pada tahun 1978, upacara pensyahadatan dilakukan terhadap 653 orang masyarakat Karo di Lau Buluh. ${ }^{9}$

Dari tahun ke tahun jumlah umat Islam di Tanah Karo terus mengalami peningkatan. Data dari tahun 1950-an diperkirakan umat Islam berjumlah 5.000 orang. Kemudian pada tahun 1960-an umat Islam di Tanah

\footnotetext{
${ }^{6}$ Mahmud Yunus, Sejarah Pendidikan Islam di Indonesia, cet. Ke-3, (Jakarta: Mutiara Sumber Widya,1992), hlm. 10-11.

${ }^{7}$ Azhari Akmal, Tarigan, Tuan Guru H. Sulaiman Tarigan: Menyemai Islam di Tanah Karo Melalui Dakwah Kultural, cet. Ke-1, (Jakarta: Yayasan Sirajul Huda, 2007), hlm. 163.

${ }^{8}$ Bujur Sitepu, Mengenal Kebudayaan Karo, (Bujur Sitepu, t.tp., 1978) hlm. 47.

${ }^{9}$ Irvan Mustafa Sembiring, Sejarah Pondok Pesantren Sirajul Huda Tiga Binanga Tanah Karo (Tesis UIN Sumatera Utara, 2016), hlm. 3.
} 
Karo telah mencapai 10.000 orang. Tahun 1966 umat Islam di Tanah Karo telah mencapai 76.525 orang atau $28,2 \%$ dari seluruh penduduk. Tahun 1997 umat Islam mencapai 78.740 jiwa atau 28,14 \% dari 279.810 jiwa masyarakat Karo (Akmal Tarigan, 2007: 257). Bahkan hingga tahun 2014 jumlah umat Islam telah mencapai 87.492 jiwa dari seluruh penduduk Karo yang berjumlah 382.622 jiwa. Walaupun terjadinya peningkatan jumlah umat Islam di Tanah Karo namun ini tidak mempengaruhi status minoritas tersebut. ${ }^{10}$

Sulaiman Tarigan merupakan salah satu orang yang mendakwahkan Islam di Tanah Karo. Situasi keislaman di Tanah Karo masih sangat minim membuat dakwah Islam di Tanah Karo belum sepenuhnya berhasil. Untuk itu, Sulaiman Tarigan berpikir merumuskan strategi dakwah Islam agar tidak berhenti ketika tidak ada pendakwah. Semenjak masuk Islam, ia bolak balik Kabanjahe dan Aceh Tenggara untuk mempelajari agama Islam. Ilmu yang dipelajari langsung diajarkan kepada masyarakat Muslim Karo dengan model pengajian sederhana di Tiga Beringin pada tahun 1925 M. Kemudian pada tahun $1936 \mathrm{M}$ pengajian tersebut dipindahkan dari Tiga Beringin ke Kuala Baru yang masih sama-sama dalam kecamatan Tiga Binanga. ${ }^{11}$

Pengajian yang dibentuk Sulaiman Tarigan berkembang menjadi pesantren Sirajul Huda yang berlokasi di Tiga Binanga yang pada mulanya bernama Madrasah Sirajul Huda. Lembaga pendidikan ini merupakan lembaga pendidikan Islam pertama di Tanah Karo. Atas dasar itu sangat menarik bagi penulis untuk mengkaji bagaimana sejarah pendidikan Islam di Tanah Karo. Kajian ini diperlukan untuk mengetahui sejarah Pesantren Sirajul Huda Tanah Karo yang masih tetap bertahan sampai sekarang di tengah mayoritas non Muslim. Dengan adanya penelitian ini bisa memberikan informasi tentang perkembangan dan strategi bertahan lembaga pendidikan Islam di Tanah Karo.

\section{Metode Penelitian}

Jenis penelitian ini adalah penelitian kualitatif (qualitative research). Istilah penelitian kualitatif dimaksudkan sebagai jenis penelitian yang temuan-temuannya mengutamakan proses dan tidak diperoleh melalui

\footnotetext{
${ }^{10}$ Pusat Statistik, 2014.

${ }^{11}$ Tridah Bangun, H. Sulaiman Tarigan : Pelopor/Pengembang Agama Islam di Tanah Karo Perintis dan Pejuang Kemerdekaan Republik Indonesia, cet. Ke-2, (Jakarta: t.p., 2003), hlm. 28.
} 
prosedur statistik atau bentuk hitungan lain. Seperti penelitian tentang kehidupan, riwayat, dan perilaku seseorang, peranan organisasi, gerakan sosial, atau hubungan timbal-balik. ${ }^{12}$

Penelitian ini merupakan metode penelitian sejarah. Menurut Gilbert J. Garraghan dalam Dudung Abdurrahman, bahwa metode penelitian sejarah adalah seperangkat aturan dan prinsip sistematis untuk mengumpulkan sumber-sumber sejarah secara efektif, menilainya secara kritis, dan mengajukan sintesa dari hasil-hasil yang dicapai dalam bentuk tertulis. ${ }^{13}$

Penelitian ini menggunakan pendekatan sosiologis. Kuntowijoyo mengatakan penelitian yang objeknya adalah pesantren, sangat erat dengan hubungan agama. Pesantren termasuk dalam kategori lembaga sosial yang sama seperti masjid, surau dan lain sebagainya. Kuntowijoyo mengatakan bahwa agama adalah sebuah institusi sosial yang bisa menjadi kajian sejarah. Banyak tema dan topik yang bisa dibicarakan seperti mengenai perubahan sosial dilihat dari segi model evolusi sejarah yang terjadi pada perubahan pendidikan, baik itu pesantren, madrasah, maupun sekolah Setelah seseorang memilih topik penelitian, mula-mula yang harus dilakukan bagi seorang peneliti atau sejarawan adalah mengumpulkan semua saksi mata yang mengetahui tentang periode sejarah tersebut. Dengan adanya saksi mata tersebut akan menyiapkan bagi sejarawan untuk menerima informasi yang diperlukan. ${ }^{14}$

Dalam hal ini peneliti akan mengumpulkan sumber-sumber data yang berkaitan dengan penelitian ini. Untuk mengumpulkan data-data tersebut, penulis menggunakan beberapa teknik dalam pengumpulan data, yaitu observasi, dokumentasi dan wawancara .

\section{Hasil Penelitian dan Pembahasan}

\section{Berdirinya Pesantren Sirajul Huda}

Yayasan Pendidikan Islam Sirajul Huda pada dasarnya merupakan usaha berkesinambungan perjuangan umat Islam Singalor Lau di bidang pendidikan dan dakwah yang telah dimulai sejak awal masuknya Islam di Tanah Karo. (Petunjuk Program Yayasan Sirajul Huda). Pesantren ini

\footnotetext{
${ }^{12}$ Suwandi \& Busrowi, Memahami Penelitian Kualitatif, (Jakarta: Rineka Cipta, 2008) hlm. 21.

13 Dudung Abdurrahman, Metodologi Penelitian Sejarah Islam, (Yogyakarta: Penerbit Ombak, 2011), hlm. 103.

${ }^{14}$ Kuntowijoyo, Metodologi Sejarah, ed. Ke-2, (Yogyakarta: Tiara Wacana Yogya, 2003), hlm. 88 $\& 166$.
} 
sekarang berada di Kuala Baru. Keberadaannya merupakan kesinambungan syiar dakwah dan pendidikan Islam yang telah dirintis sejak tahun 1904. Persisnya setelah Teungku Muda Telaga Mekar dari Aceh Tenggara mengislamkan Sibayak Juan dan istrinya, Pajoh boru Sebayang, beserta anak menantunya, Njalapi Tarigan (Muhammad Said Tarigan) dan Ngambihi Boru Sebayang. Walaupun Juan Tarigan tidak sempat untuk mengembangkan ajaran Islam di berbagai daerah Tanah Karo, tetapi ia berhasil mengajak keluarganya. Tidak lama setelah memeluk Islam, Juan Tarigan pun akhirnya meninggal dunia.

Seiring dengan Islamnya keluarga Sibayak Juan Tarigan, salah satunya anak yang bernama Persadaan Tarigan atau yang lebih dikenal Sulaiman Tarigan merupakan salah satu yang sangat unggul dalam penguasaan agama Islam. Kesadaran Sulaiman Tarigan dalam menatap masa depan agama Islam di Tanah Karo, memotivasi dirinya untuk mempersiapkan kader penerus perjuangan untuk mengembangkan Islam di Tanah Karo. Keinginan tersebut pada akhirnya tercapai berkat ketekunan dan kegigihan dalam berdakwah dan mendidik murid-muridnya. Hal ini dapat dilihat keberhasilannya yang telah melahirkan para dai dan guru-guru yang dapat diandalkan untuk melanjutkan dakwah Islam di Tanah Karo. ${ }^{15}$

Proses perkembangan pendidikan Islam beriringan dengan proses dakwah Islam di Tanah Karo. Upaya mempersiapkan kader pendakwah yang pertama sekali dilakukan oleh Sulaiman Tarigan adalah dengan mendirikan sebuah Pengajian di Tiga Beringin yang kemudian dikenal dengan nama Pesantren Sirajul Huda. Konsep ini dilakukan sesuai dengan pengalaman belajar Sulaiman Tarigan ketika belajar di Aceh Tenggara. Proses pembelajaran pendidikan Islam berlangsung dalam bentuk pengajian sudah terbentuk dan terstruktur secara sederhana. Kurikulum yang digunakan adalah sebuah kitab Arab Jawi.

Hal yang mendasari Sulaiman Pada tahun 1925 berkeinginan untuk mendirikan pengajian di Tiga Beringin karena banyak murid-murid yang ingin belajar Islam. Selepas Maghrib dan makan malam, semua orang Islam dari kampung-kampung tersebut datang ke Tiga Beringin untuk belajar agama Islam. Dan di Tiga Beringin tersebut telah didirikan langgar/mushalla. Di mushalla itulah orang-orang tersebut belajar di waktu malam hari. Dan bagi orang yang tidak pulang ke rumah disediakanlah

\footnotetext{
${ }^{15}$ Irvan Mustofa Sembiring, op. cit., hlm. 70.
} 
tempat untuk menginap malam. Hal ini juga sekaligus untuk tempat menginap murid-murid Sulaiman Tarigan yang datang dari daerah Dairi. Mereka pada malam hari datang ke tempat pengajian dengan memakai obor untuk menimba ilmu kepada tuan guru. Setelah sekitar satu minggu Sulaiman Tarigan mengajarkan ilmunya di tempat pengajian tersebut, ia akan kembali menunt ut ilmu agama ke Kutacane dengan berjalan kaki.

Setelah banyak penduduk yang memeluk agama Islam, maka dibangunlah gubuk-gubuk di Tiga Beringin. Gubuk-gubuk yang didirikan tersebut pada dasarnya adalah tempat untuk orang yang bermukim. Seiring dengan perkembangan Islam di sekitar daerah tersebut, maka orang Islam yang berada di Desa Keriahen membentuk desa baru dengan nama Desa Pancur Jawi. Orang Islam di Desa Pergendangen membentuk kampung baru dengan nama Desa Simpang Pergendangen. Begitu juga orang Islam di Kuala membentuk kampung Baru dengan nama Desa Kuala Baru.

Pada tahun 1936 Pondok Pengajian yang tradisional yang dulunya berada di Tiga Beringin dipindahkan ke Kuala Baru persisnya tempat berdirinya Pesantren Sirajul Huda saat ini. Setelah perpindahan tersebut ke Kuala Baru, ternyata pengajian semakin pesat perkembangannya. Hal ini ditandai dengan adanya cabang baru lembaga pendidikan Islam di Simpang Pergendangen yang berpusat kepada pengajian di Kuala Baru. Untuk memperkaya sumber ilmu, maka didatangkalah guru-guru dari Kutacane antara lain Teungku Juned, Teungku H. Hasan Sikedang dan Teungku Wan Dah. $^{16}$

Perpindahan pengajian dari Tiga Beringin ke Kuala Baru, bukan saja karena perkembangan umat beragama Islam pada saat itu, tetapi juga seiring dengan perpindahan pekan ke Tiga Binanga. Pekan yang terjadi pada setiap hari selasa, dahulu sebelum ke Tiga Binanga mulanya bertempat di Tiga Beringin. Dengan perpindahan tersebut, maka memungkinkan tempat pengajian tersebut dijangkau dari berbagai daerah di Tiga Binanga karena berada di tempat yang strategis.

Berdasarkan catatan Mukaddimah petunjuk singkat pelaksanaan Program Pendidikan Tahun Ajaran 1994/1995 Yayasan Sirajul Huda menyebutkan bahwa pada tahun 1936, Pengajian yang dibangun oleh Sulaiman Tarigan di Tiga Beringin tersebut dipindahkan ke Desa Kuala Baru Tiga Binanga dengan gurunya ustadz H. Abd. Manaf Tarigan dan

\footnotetext{
${ }^{16}$ Tridah Bangun, op. cit., hlm. 32.
} 
Abdul Salam Tarigan. Dari penjelasan ini perpindahan pengajian dari Tiga Beringin ke Kuala Baru menunjukkan bahwa telah ada murid dari Sulaiman Tarigan yang menjadi guru dalam pengajian tersebut.

Perpindahan pengajian dari Tiga Beringin pada tahun 1936, berbarengan dengan selesainya pembangunan Masjid Jami' Kuala Baru berkat wakaf saudagar India bernama Haji Qasim dan sumbangan tanah dari kepala Desa Kuala, yaitu Bogoh Sebayang. Hal ini juga menjadi salah satu alasan pemindahan pengajian ke Kuala Baru Tiga Binanga. Untuk menjalankan aktifitas pengajian pada masa ini, Sulaiman Tarigan dibantu oleh beberapa murid dan keponakannya, yaitu Abdul Manaf Tarigan, Abdul Salam Tarigan, Muhammad Saleh Tarigan, Abdul Rahman Tarigan dan Abdul Rahim Tarigan.

Pada 22 Juli 1946 pengajian di Simpang Pergendangen itu digabungkan kembali ke Kuala Baru. Untuk menyediakan ruang belajar, kaum Muslimin Tiga Binanga bergotong-royong mendirikan bangunan darurat beratap rumbia. Sejak perpindahan pengajian tersebut telah ada rencana untuk membuat sebuah nama. Pada saat itu seiring dengan perkembangan umat Islam di daerah Tanah Karo, khususnya daerah Tiga Binanga, maka pemuka-pemuka agama Tiga Binanga melakukan musyawarah untuk membuat sebuah nama dari madrasah yang didirikan. Hasil musyawarah tersebut, menyepakati bahwa nama dari sekolah tersebut sesuai dengan cita-cita Sulaiman Tarigan adalah Sirajul Huda yang berarti "cahaya petunjuk". 17

Pada tahun 1947 pengajian ini secara resmi diberi nama Madrasah Islamiyah Sirajul Huda dan dalam perkembangan selanjutnya pada tanggal 22 juni 1968 dibentuk Yayasan Sirajul Huda sebagai pengelola tunggal Madrasah dengan akta notaris Rusli 44 tanggal 11 September 1968 Medan.

Pesatnya perkembangan Islam di Singalor Lau, mendorong umat Islam untuk merencanakan pembangunan sebuah masjid sebagai pusat aktivitas keagamaan. Untuk mewujudkan rencana mulia itu, mereka bermusyawarah. Mereka memilih Kuala Baru sebagai lokasinya. Sebab letaknya yang berdekatan dengan pekan Tiga Binanga sangat strategis bagi pengembangan dakwah Islam. Mereka juga memilih Sulaiman Tarigan dan Rahmat Sebayang untuk memimpin panitia pembangunan itu. Pasangan ini memang serasi, sebab selain ber-ipal dan keahlian mereka juga saling

\footnotetext{
${ }^{17}$ Irvan Mustofa Sembiring, op. cit., hlm. 65.
} 
melengkapi. Sulaiman terkenal sebagai ulama, sementara Rahmat Sebayang terkenal karena kemampuannya menulis dan membaca huruf latin. ${ }^{18}$

Upaya itu kian lengkap ketika Sulaiman Tarigan dan Rahmat Sebayang yang sedang mencari dana ke Medan kebetulan singgah untuk menunaikan shalat Jum'at di Masjid Gang Bengkok, Kesawan. Di masjid itu mereka bertemu dengan Haji Qasim, seorang saudagar India yang punya kantor perwakilan dagang di kawasan itu. Saudagar ini terkenal dermawan dan kerap mewakafkan hartanya untuk membantu umat Islam, khususnya umat di daerah-daerah terpencil. Sulaiman Tarigan dan Rahmat Sebayang memohon bantuan dana bagi pembangunan rumah guru dan masjid. Beberapa waktu kemudian, permohonan itu dijawab Haji Qosim dan mengirimkan dua orang utusan ke Tiga Binanga. Melalui kedua utusan itulah Sulaiman Tarigan dan Rahmat Sebayang menerima dana pembangunan rumah guru sebesar Rp. 125. Sementara dana pembangunan masjid yang jumlahnya Rp. 200, langsung dikirimkan Haji Qasim dari seorang yang bernama Kalkuta, dan diterima lewat pos oleh Sulaiman Tarigan dan Rahmat Sebayang.

Tidak hanya masjid yang direnovasi dengan gedung permanen, tetapi juga membangun gedung sebagai ruang belajar madrasah yang aktif pada saat sore hari. Sebagaimana dalam penjelasan sebelumnya disebutkan bahwa awalnya bangunan madrasah tersebut dengan bangunan darurat berdinding tepas dan beratap rumbia, kemudian direnovasi atas bantuan kolonel Djamin Gintings dan pada masa H. KP. Malik Tarigan membuat ruangan belajar madrasah yang bersampingan dengan masjid. Dalam perkembangan selanjutnya gedung madrasah tersebut berubah menjadi asrama putra.

Sentral lembaga Pendidikan Islam pada saat itu adalah Kuala Baru. Lembaga pendidikan di Simpang Pergendangen adalah cabang dan pengembangan dari Kuala Baru yang sebelumnya bertempat di Tiga Beringin. Saman Doly mengatakan bahwa pengajian Singalor Lau selangkah lebih maju ketika Haji Fakhruddin Tarigan, pada tahun 1944, membangun dua ruang belajar di Simpang Pergendangen. Sejak saat itu, diterapkan metoda belajar in-door (dalam kelas). Sebagai gurunya ditunjuk Muhammad Saleh Wahab Perangin-angin. Namun, kelas pengajian itu terhenti ketika

\footnotetext{
${ }^{18}$ Saman Dooly Tarigan, Madrasah Sirajul Huda dan Tuan Guru Haji Sulaiman Tarigan dalam Peta Perkembangan Islam Tanah Karo, (Jakarta: Juanta Tunas Mulia, 2003), hlm. 43.
} 
umat Islam terpaksa mengungsi ke Kutacane untuk menghindari agresi Belanda.

Ironisnya, bangunan wakaf dari Haji Fakhruddin Tarigan tersebut dibakar oleh Belanda pada saat mengungsi tahun 1946. Sekembali dari pengungsian, maka pengajian tersebut digabungkan kembali ke Kuala Baru dengan bangunan yang darurat hasil gotong royong kaum Muslim pada tempat tersebut. (Petunjuk Singkat Pelaksanaan Program Pendidikan Yayasan Sirajul Huda.)

Walaupun bangunan belajar hancur, namun semangat umat Islam Singalor Lau tidak surut untuk belajar. Agar pengajian bisa dilanjutkan kembali, umat Islam Singalor Lau bergotong royong mendirikan bangunan pengganti di Kuala Baru. Akhirnya pada tahun 1947, bangunan itu rampung. Bangunan itu memang amat sederhana, namun justru dalam kesederhanaan itulah mereka menggantungkan harapan. Lewat celah dinding tepas bangunan itu mereka mengintip masa depan, dan lewat lubang atap jerami ruang belajar itu mereka melihat ketinggian ilmu. Untuk melengkapi semua kebersahajaan itu, Muhammad Sebayang membuat sebuah papan merek berdasarkan nama yang diusulkan oleh Sulaiman Tarigan yang bertuliskan Madrasah Islamiyah Sirajul Huda. (Saman Dooly, 46-47)

Berdasarkan uraian di atas dapat dilihat bahwa pemikiran Sulaiman tarigan sudah modern dalam sistem pendidikan. Ini terlihat dari konsep dan pergerakan yang dilakukan dengan menyusun kurikulum dan sarana dan prasarana yang baik. Salah satu di antara banyak peran Sulaiman Tarigan dalam pengembangan Madrasah Sirajul Huda pasca masa pengungsian itu dan berkat upayanya bangunan darurat Madrasah Sirajul Huda sehingga pada tahun 1957 bangunan darurat bisa diganti setelah ia berhasil mendapatkan sumbangan dari Kolonel Djamin Ginting, Panglima Teritorium Bukit Barisan pada masa itu. Dengan sumbangan yang jumlahnya mencapai Rp. 150.000,- itu, umat Islam Singalor Lau bisa membangun lima ruang belajar baru.

\section{Kurikulum Pendidikan Awal Islam di Tanah Karo}

Istilah kurikulum digunakan dalam dunia pendidikan dan mengalami perubahan makna sesuai dengan perkembangan dan dinamika yang ada pada dunia pendidikan. Secara garis besar, kurikulum dapat diartikan sebagai seperangkat materi pendidikan dan pengajaran yang diberikan kepada murid 
sesuai dengan tujuan pendidikan yang akan dicapai. ${ }^{19}$ Pakar pendidikan Islam pada masa klasik menggunakan kata al maddah untuk pengertian kurikulum yang berarti serangkaian mata pelajaran yang harus diberikan pada murid dalam tingkat tertentu. ${ }^{20}$ Sejalan dengan perjalanan waktu, pengertian kurikulum mulai berkembang dan cakupannya lebih luas, yaitu mencakup segala aspek yang mempengaruhi pribadi siswa.

Kurikulum dalam pengertian yang modern ini mencakup tujuan, mata pelajaran (isi dan struktur program), proses belajar dan mengajar (strategi pencapaian tujuan) serta evaluasi. Bila dikaitkan dengan sistem pendidikan Islam, kurikulum mengandung makna sebagai suatu rangkaian program yang mengarahkan kegiatan belajar mengajar yang terencana dengan sistematis dan berarah tujuan, serta menggambarkan cita-cita ajaran Islam. Untuk pesantren, kurikulum berisikan materi untuk pendidikan seumur hidup (long life education). Materi pokok kurikulum pendidikan Islam adalah bahanbahan, aktivitas, dan pengalaman yang mengandung unsur ketauhidan.

Berdasarkan urian di atas sejarah pendidikan Islam di Tanah Karo dimulai ketika Sulaiman Tarigan mulai dakwahnya untuk menyebarkan Islam. Sebagaimana yang telah dijelaskan sebelumnya, bahwa pengajian yang semulanya berada di Tiga Beringin, tidak memakai kurikulum yang formal sebagaimana yang berlaku menurut kepemerintahan. Hanya saja pada saat itu mulai dari berdirinya Pengajian di Tiga Beringin hingga berpindah ke Kuala Baru sampai sekitar Tahun 1958 selalu mempelajari khusus tentang agama, yang bersifat fardhu 'ain seperti fikih, tauhid, tasawuf, serta juga mempelajari cara membaca dan menulis huruf Alquran dan melayu.

Kurikulum pendidikan Islam bersifat rekonstruktif selektif yang berupaya menampilkan suatu sistem pendidikan Islam terpadu yang tetap menjaga prinsip keserasian dan keseimbangan individu yang menggambarkan perwujudan fungsi utama manusia sebagai sebagai 'abd Allah dan khalifah al ard. Ilmu pengetahuan dewasa ini telah terkontaminasi oleh pemikiran-pemikiran dari dunia Barat yang sekuler dan bertentangan dengan nilai-nilai ajaran Islam. Oleh karena itu, perlu adanya suatu upaya melalui gerakan "Islamisasi ilmu pengetahuan" dengan mengambil segi-segi positif dari perkembangan-perkembangan modern seselektif mungkin, meskipun hal itu datangnya dari Barat yang diformulasikan dalam kurikulum

\footnotetext{
${ }^{19}$ Zuhairini, dkk., Metodologi Pendidikan Agama, (Solo: Ramadhani, 1993), hlm. 42.

${ }^{20}$ Abudin Nata, op. cit., hlm. 115.
} 
pendidikan Islam. Kurikulum pendidikan yang diterapkan yakni berusaha mengintegrasikan ilmu pengetahuan yang bersifat fard 'ain dan fard kifayah. Dan pada prinsipnya ini yang tertuang dalam konsep ta'dib sebagai suatu proses penanaman adab yang didalamnya telah mencakup 'ilm dan amal

Berdasarkan informasi yang penulis terima dari beberapa informan, bahwa pada mulanya kurikulum pembelajaran yang dilakukan oleh Sulaiman Tarigan pada pengajian di Tiga Beringin tersebut tidak memakai kurikulum sebagaimana yang berlaku pada saat sekarang ini yang merujuk kepada kurikulum pemerintah. Mereka menggunakan kurikulum yang diproleh dari Kutacane ketika Sulaiman Tarigan belajar di sana. Dalam perkembangan selanjutnya, Sulaiman Tarigan yang terus menerus menimba ilmu agama Islam hingga akhirnya ilmu yang dimiliki semakin dalam dan mampu membaca dan mengajarkan kitab seperti perukunan, kitab barjanzi, dan juz 'amma. Pada tahap ini Sulaiman Tarigan tidak lagi mengajarkan tentang Islam dengan sistem merekam apa saja yang disampaikan gurunya kemudian menyampaikannya kepada masyarakat Karo. Tetapi Sulaiman Tarigan telah memiliki panduan tetap tentang apa saja yang diajarkan untuk masyarakat Karo dalam mengajarkan kitab perukunan.

Berbagai ilmu yang dipelajari oleh Sulaiman Tarigan, ia ajarkan kepada masyarakat Karo di sebuah pengajian Tiga Beringin. Sekalipun Sulaiman Tarigan banyak belajar agama kepada banyak ulama di Aceh dan Medan, namun proses belajar yang dilakukan tidak secara formal. Tidak ada informasi yang mengatakan bahwa Sulaiman Tarigan telah menamatkan sebuah kitab klasik dalam bidang fikih, tauhid atau tasawuf sebagaimana yang umumnya terdapat pada santri-santri yang telah lulus pesantren.

Di antara kitab-kitab yang pernah diajarkan dan dibaca dengan baik oleh Sulaiman Tarigan adalah kitab perukunan, begitu juga kitab barjanzi dan juz 'amma. Kitab perukunan berisi materi ajaran Islam, khususnya dalam bidang akidah dan fikih, sedangkan kitab barjanzi berbicara tentang sejarah Rasul, dan kitab juz 'amma digunakan untuk mengajarkan membaca Alquran.

Kitab perukunan merupakan sebuah kitab yang ditulis dengan huruf jawi (Arab Melayu) yang memuat himpunan segala doa dan zikir, syahadat, rukun Islam dan tata cara pelaksanaannya, thaharah (bersuci), lafaz-lafaz niat shalat fardhu dan sunnat serta amalan-amalan untuk dilaksanakan kaum Muslimin. Bagi masyarakat Karo muslim, pada umumnya ajaran Islam merupakan hal yang baru. Atas dasar itu sangat tepat jika kitab perukunan 
itu diajarkan oleh Sulaiman Tarigan kepada masyarakat muslim Karo. Karena dalam kitab perukunan tersebut dapat belajar tentang fardhu 'ain yang merupakan perkara-perkara ibadah yang wajib dilaksanakan dalam kehidupan sehari-hari.

Semenjak Sulaiman Tarigan memeluk Islam, ia sangat gigih mempelajari agama Islam. Ia tidak hanya belajar tentang Islam, tetapi juga mengembangkan agama Islam ke masyarakat Karo yang telah memeluk Islam. Untuk mengembangkan Islam, Sulaiman Tarigan mendirikan sebuah pengajian di Desa Tiga Beringin. Dalam hal ini, berapa banyak ilmu yang ia dapatkan dari gurunya, begitu pula yang diajarkan kepada murid-muridnya. Sulaiman Tarigan tidak berlama-lama menginap untuk menuntut ilmu seperti santri-santri dalam sebuah pondok pesantren pada umumnya. Jika ia merantau ke Aceh untuk mendapatkan satu ilmu dalam kurun waktu satu minggu, maka ia akan kembali pulang ke Tanah Karo untuk mengajarkan ilmu yang didapatkannya tersebut. Jadi, ia mengamalkan konsep belajar dan mengajar, dan dengan konsep tersebut, maka ilmu yang didapat akan melekat di hati.

Bagaimana Sulaiman Tarigan menerima ilmu-ilmu agama Islam dari gurunya, begitu pulalah cara yang ditempuhnya dalam menyampaikan ajaran-ajaran Islam ke tengah-tengah masyarakat. Biasanya Sulaiman Tarigan duduk di atas tikar dan terkadang menggunakan bangku, kemudian ia membaca kitab perukunan, sementara murid-muridnya mendengarkannya dengan serius. Metode yang diterapkan oleh Sulaiman Tarigan tersebut sama seperti metode wetonan sebagaimana yang diterapkan oleh pesantrenpesantren salafi, yaitu suatu metode belajar mengajar dimana murid mengikuti pelajaran dengan duduk mengelilingi guru yang menerangkan pelajaran. Sedangkan para murid menyimak pelajaran yang diberikan oleh guru. Metode seperti ini juga disebut dengan metode halaqah.

Pada bagian-bagian tertentu dalam menjelaskan istilah-istilah dalam ajaran Islam yang dipandangnya perlu mendapatkan penjelasan yang lebih dalam, maka Sulaiman Tarigan menjelaskan materi tersebut, dan jika kurang mengena penjelasan tersebut kepada muridnya, maka beliau mencari padanannya dalam budaya Karo. Selanjutnya ia segera menghubungkannya dengan tradisi dan adat istiadat Karo. Dengan metode seperti ini, jamaahnya merasa sangat dekat dan mengenal materi apa saja yang diajarkan oleh sang guru. 
Syarifuddin mengatakan walaupun hanya al-fătihah yang didapatkan, Tuan guru pulang dan langsung mengajarkannya kepada orang-orang yang memeluk Islam. Tentu saja murid-murid pada saat itu telah tua-tua, bahkan sebagai murid dari Sulaiman Tarigan banyak yang buta huruf. Sungguhpun demikian murid buta huruf tersebut cepat dapat mempelajari Islam dengan baik. Hal ini karena metode pengajaran Sulaiman Tarigan pada saat itu langsung menuju untuk mempraktikkan apa yang dipelajari. Sulaiman Tarigan menyuruh pada muridnya untuk selalu membaca basmallah ketika akan melakukan segala kegiatan. Bagi kaum petani yang umumnya suku Karo, jika memulai untuk mencangkul, Sulaiman Tarigan menyuruh mereka untuk membaca basmallah. (Syarifuddin Tarigan, wawancara 22 Agustus 2016).

Dari penjelasan tersebut menjelaskan bahwa Sulaiman Tarigan dalam menerapkan metode mengajarnya tidak hanya dalam bentuk halaqah, ceramah, tanya jawab dalam pondok pengajian. Tetapi ia juga menerapkan metode latihan dengan langsung mempraktikkan atau mengamalkan apa saja yang telah diajarkan di mana pun berada. Sebagai seorang guru, Sulaiman Tarigan merupakan guru yang baik, konsisten, penuh integritas dan benarbenar membimbing murid-muridnya. Sekalipun Sulaiman Tarigan tidak pernah marah terhadap murid-muridnya sepanjang berhubungan dengan ketidakmampuan menangkap pelajaran, namun ia keras dalam kaitannya dengan perilaku murid-muridnya yang menyimpang dari ajaran Islam. Sulaiman Tarigan tidak segan-segan menegur orang Islam dalam melanggar syariat. Seperti bila ada orang yang Islam atau orang lain yang mandi di pancuran umum Kuala Baru yang tidak mengenakan kain basahan mandi, maka ia tidak segan-segan mengusir orang tersebut karena telah melanggar syariat Islam di depan umum. Bagi Sulaiman Tarigan, masalah-masalah seperti ini dapat merendahkan agama Islam di hadapan agama lain.

Setelah Sulaiman Tarigan menyebut nama-nama sahabat, beliau meminta jamaah atau muridnya untuk menghafalkan nama-nama sahabat tersebut dan mengulang-ulangi tugas masing-masing sahabat. Ini dilakukan mengingat murid-muridnya rata-rata telah berusia lanjut. Sulaiman Tarigan juga menggunakan metode hafalan dalam proses belajar mengajar. Metode hafalan di sini, yaitu suatu metode dimana para murid menghafal teks atau kalimat tertentu dari pelajaran yang diberikan oleh gurunya. Sebagaimana pada metode pesantren secara umum, bahwa keilmuan hanya dianggap sah dan kokoh bila dilakukan melalui transmisi dan hafalan. 
Setelah pengajian dipindahkan dari Tiga Beringin ke Kuala Baru, kemudian mengalami perkembangan ketika Haji Fakhruddin Tarigan pada tahun 1944 membangun dua ruang belajar di Simpang Pergendangen. Sejak saat itu, diterapkan metode belajar in-door (dalam kelas). Sebagai gurunya ditunjuk Muhammad Saleh Wahab Perangin-angin, sebagai ustādz muda dari Pancur Batu yang tak lain adalahss menantu Sulaiman Tarigan.

Pada awalnya pengajian Tiga Beringin hanya diikuti oleh anggota keluarga muslim yang mula-mula masuk Islam. Dalam pengajian tersebut mengkaji tentang dasar-dasar ibadah yang fardhu 'ain, ayat-ayat pendek Alquran, ketuhanan, dan akhlak. Kajian ini terus meningkat seiring dengan pulang perginya Sulaiman Tarigan ke Tanah Aceh untuk menimba ilmu agama Islam. Seiring dengan perkembangan Islam di daerah sekitar Tiga Beringin yang lahir kampung-kampung Muslim di Singalor Lau, jamaah pengajian Tiga Beringin tersebut terus bertambah. Bahkan dengan pertambahan murid tersebut ada sebahagian yang mondok di Tiga Beringin untuk belajar agama.

\section{Simpulan}

Sejarah pendidikan Islam di Tanah Karo dimulai dengan Islamnya kepada sebuah keluarga di Tiga Beringin dari Sibayak Juan Tarigan, salah satunya anak dari Juan Tarigan, yaitu Persadaan Tarigan atau Sulaiman Tarigan. Berdasarkan kesadaran Sulaiman Tarigan dalam menatap masa depan agama Islam di Tanah Karo, ia kemudian mempersiapkan kader untuk mempersiapkan orang yang meneruskan estafet perjuangan melanjutkan tugasnya mengembangkan Islam di Tanah Karo. Upaya untuk mempersiapkan kader tersebut yang pertama kali dilakukan oleh Sulaiman Tarigan adalah mendirikan sebuah Pengajian di Tiga Beringin pada tahun 1925. Pada waktu itu banyak murid-murid yang ingin belajar Islam kepada Sulaiman Tarigan. Bagi muridnya yang jauh akhirnya terpaksa mondok beberapa hari di Tiga Beringin. Demikianlah seterusnya lama-kelamaan pengajian tersebut terus berkembang secara pesat. Guru-guru pun mulai didatangkan dari Aceh Tenggara secara bergantian. Kurikulum yang formal sebagaimana yang berlaku menurut kepemerintahan. Pada saat itu mulai dari berdirinya Pengajian di Tiga Beringin hingga berpindah ke Kuala Baru sampai sekitar Tahun 1958 materi pelajaran khusus tentang agama yang bersifat fardhu 'ain seperti fikih, tauhid dan tasawuf. Selain itu, para santri juga belajar membaca dan menulis huruf Alquran dan melayu. 


\section{DAFTAR PUSTAKA}

Abdurrahman, Dudung. 2011. Metodologi Penelitian Sejarah Islam. Yogyakarta: Penerbit Ombak.

Bangun, Tridah. 2003. H. Sulaiman Tarigan : Pelopor/Pengembang Agama Islam di Tanah Karo Perintis dan Pejuang Kemerdekaan Republik Indonesia. Cet. Ke-2. Jakarta: t.p.

Daulay, Haidar Putra. 2014. Sejarah Pertumbuhan dan Pembaruan Pendidikan Islam di Indonesia. Jakarta: Kencana Prenada Media Group.

Kuntowijoyo. 2003. Metodologi Sejarah. Ed. Ke-2. Yogyakarta: Tiara Wacana Yogya.

Nata, Abuddin. 2008. Manajemen Pendidikan. Cet. Ke-3. Jakarta: Kencana Prenada Media Group.

Petunjuk Singkat Pelaksanaan Program Pendidikan Tahun Ajaran 1994/1995, Yayasan Sirajul Huda.

Sitepu, Bujur. 1978. Mengenal Kebudayaan Karo, t.tp.

Sembiring, Irvan Mustafa. 2016. Sejarah Pondok Pesantren Sirajul Huda Tiga Binanga Tanah Karo. Tesis UIN Sumatera Utara.

Somad, Burlian. 1981. Beberapa Persoalan dalam Pendidikan Islam. Jakarta: Al-Ma'arif.

Sumber: Badan Pusat Statistik Kabupten Karo 2014.

Suwandi dan Busrowi. 2008. Memahami Penelitian Kualitatif. Jakarta: Rineka Cipta.

Tarigan, Saman Dooly. 2003. Madrasah Sirajul Huda dan Tuan Guru Haji Sulaiman Tarigan dalam Peta Perkembangan Islam Tanah Karo. Jakarta: Juanta Tunas Mulia.

Tarigan, Azhari Akmal. 2007. Tuan Guru H. Sulaiman Tarigan: Menyemai Islam di Tanah Karo Melalui Dakwah Kultural. Cet. Ke-1. Jakarta: Yayasan Sirajul Huda.

Yunus, Mahmud. 1992. Sejarah Pendidikan Islam di Indonesia. Cet. Ke-3. Jakarta: Mutiara Sumber Widya.

Zuhairini, dkk. 1993. Metodologi Pendidikan Agama. Solo: Ramadhani. 